Article

\title{
Analysis of the Impact of the COVID-19 Crisis on the Hungarian Employees
}

\author{
Peter Karacsony *(D), Kornél Krupánszki and Imrich Antalík
}

check for updates

Citation: Karacsony, P.; Krupánszki, K.; Antalík, I. Analysis of the Impact of the COVID-19 Crisis on the

Hungarian Employees. Sustainability 2022, 14, 1990. https://doi.org/

$10.3390 /$ su14041990

Academic Editor: Katarína Stachová and Zdenko Stacho

Received: 28 December 2021

Accepted: 7 February 2022

Published: 10 February 2022

Publisher's Note: MDPI stays neutral with regard to jurisdictional claims in published maps and institutional affiliations.

Copyright: (c) 2022 by the authors. Licensee MDPI, Basel, Switzerland. This article is an open access article distributed under the terms and conditions of the Creative Commons Attribution (CC BY) license (https:// creativecommons.org/licenses/by/ $4.0 /)$.

\author{
Department of Economics, J. Selye University, 94501 Komárno, Slovakia; 123199@student.ujs.sk (K.K.); \\ antaliki@ujs.sk (I.A.) \\ * Correspondence: karacsonyp@ujs.sk
}

\begin{abstract}
The economic crisis in the wake of the coronavirus epidemic is affecting the lives, jobs and incomes of a lot of people. Certain sectors of the economy have come to a standstill or stalled for a time, causing many to lose their jobs and be forced to pursue other career options than originally planned. The COVID-19 pandemic caused a deep economic crisis that caused workers to feel insecure, which also had a negative impact on the lives and characteristics of individuals at work. In the course of our research, we conducted a survey of employees in small and medium-sized enterprises in Hungary in order to find out how the coronavirus crisis affected them. In Hungary, the sectors most affected by the epidemic (e.g., hospitality, tourism, automotive) had an intense impact, as the consequences of restrictions on mobility and social distance emerged in the very early stages of the crisis. The survey was conducted in July 2021 after the end of the second wave of the epidemic, with a total of 613 participants. Our results confirmed that the coronavirus crisis had a significant impact on the respondents' feelings of job insecurity and financial situation. There is a significant connection between the downsizing of Hungarian small and medium-sized enterprises and the feeling of job insecurity among employees. There was also a significant link between the organizational measures taken against the crisis and the financial situation of the employees. Thus, based on the results obtained, it can be concluded that the coronavirus crisis has had a negative impact on the lives of individuals through the workplaces.
\end{abstract}

Keywords: human resources; COVID-19; job insecurity; crisis; small and medium-sized enterprises; Hungary

\section{Introduction}

The disease caused by the 2019 coronavirus (COVID-19) was first detected in China in late December 2019 and soon spread rapidly around the world. On 11 March 2020, the WHO (World Health Organization) declared COVID-19 a "pandemic" [1]. According to Worldometer data as of December 17, 2021, the number of coronavirus cases worldwide exceeded 273 million and claimed the lives of more than 5.3 million patients [2]. Although several effective vaccines against the virus have been developed to date [3], nations are still applying previous control guidelines made to control the spread of SARS-CoV-2 [4,5]. Protective measures include social exclusion, closure of educational institutions, restrictions on events and social gatherings, regulations on the use of personal protective equipment (especially masks), travel restrictions, border closures and ongoing testing [6-8]. In addition, some nations have declared a state of emergency and introduced a partial lockdown to control the current third wave $[9,10]$, which has restricted the movement of people and thus has an impact on the world of work [11-13]. Working from home is becoming more widespread in the world [14-17]. There has also been a significant increase in work from home in countries where this has not been significant before, e.g., in the case of Hungary or Slovakia [18]. The introduction of teleworking and the effective implementation of the digital transformation will ensure the sustainability of organizations and workplaces 
during the coronavirus epidemic [19]. Teleworking can have an impact on the long-term sustainability of organizations by reducing costs and increasing employee productivity [20].

In addition to the economic and financial effects of the coronavirus crisis, the social effects are also significant [21,22]. The measures taken are causing discomfort, anxiety, depression and growing fear, which is why people are also significantly affected by the pandemic [23]. Above all, when an individual becomes infected, it disrupts his or her normal life activities. They are unable to work, thus losing their regular income and if there is an elderly person or child in the family, it becomes difficult to take care of them. In addition to restricting access to work, they must also restrict their social life in order to protect their own health and the health of others [24,25]. Governments are also constantly introducing various restrictions to control the spread of the disease, which also has an impact on the individual's daily life [26]. Individuals have less and less patience, as the current wave of protests in the world shows [27]. There is still a lot of uncertainty about when and how the coronavirus crisis will end. Newer manifestations of the COVID-19 epidemic, its prolongation over time and the international and domestic government responses to them also have a significant impact on the development of economic processes; therefore, a number of risk factors continue to threaten labor market participants.

The crisis emerging from the coronavirus epidemic is in many ways different from the most recent crisis in 2008 [28]. The financial crisis of 2008 stemmed from the failure of credit market risk management in America [29]. In contrast, the explosion of the coronavirus can be considered a one-off shock for which previously proven solutions could not be used [30]. The crisis caused by the coronavirus epidemic poses a challenge to the global economy. As a result of the drastic drop in demand and the forced quarantine measures, the crisis in the world of work was immediate, with immediate consequences for the lives and livelihoods of millions of people [31,32]. In the sectors most severely affected by the epidemic (such as tourism, hospitality, event management and the automotive industry), workers have had to face mass redundancies and forced unpaid leave locally and globally [33,34].

Through small and medium-sized enterprises in Hungary, our study attempts to present and analyze the impact of the coronavirus crisis on the daily lives of employees, and how and in what way they have affected their sense of security and financial well-being at work.

The present study is structured as follows: Section 2 presents a review of the literature and a background to research hypotheses. Section 3 describes the research methodology in detail. This is followed by a description of the results found in the research. At the end of the study, the discussion, conclusions and research constraints are included.

\section{Theoretical Background and Hypothesis Development}

\subsection{Effects of COVID-19 on Labor Market}

The labor market consequences of economic shocks are usually delayed, but the crisis caused by COVID-19 differs from previous crises in that it has had an immediate negative impact on the world of work [18]. Initially, the epidemic caused a supply shock, cessation of production by disrupting supply chains and shutting down jobs for epidemiological reasons. Production chains have thus been disrupted, and supply and demand have collapsed in a short period of time in a number of sectors due to the epidemic and measures to prevent it from spreading. The decline in consumption has led to a prolonged demand crisis in several sectors [35]. According to ILO (International Labour Organization), the working-hour losses in 2020 were approximately four times greater than during the global financial crisis in 2009. The decline in working hours in 2020 translated into employment losses. Employment losses were highest in the Americas, and lowest in Europe and Central Asia, where job retention schemes have supported the reduction in working hours. The global employment losses were 114 million jobs in 2020 relative to 2019. The employment losses were higher for women (5.0 per cent) than for men, and for young workers ( 8.7 per cent) than for older workers [36]. However, losses do not affect individual sectors equally. Currently, about 1.25 billion people, about $38 \%$ of the global total, work in the sectors most 
affected by the epidemic (trade, hospitality, manufacturing, business services, etc.) [37]. The epidemic has led to a dramatic drop in the volume of world trade. Restrictive effects of government measures, e.g., mandatory closures at home and abroad, physical distancing, and other forms have adversely affected production prospects in most countries $[38,39]$. These multiple demand and supply shocks have had a profound effect on the already fragile labor markets [40,41]. The negative impact of the coronavirus crisis on jobs has been more pronounced for micro, small and medium-sized enterprises [42], as these enterprises are "over-represented" in the sectors most affected by COVID-19 [43], including accommodation and food, retail and wholesale, travel and transportation sectors [44]. This is also a particularly painful point, as the majority of European and thus Hungarian jobs are provided by SMEs [45]. In addition to the above, other negative effects of the epidemic on the world of work must be taken into account. Losing a job can be a source of both individual and organizational problems. For many, work is also the sole source of income, so in addition to financial problems, its loss also has a significant effect on the motivation of individuals [46]. The transformation of work can also negatively affect the sustainability of organizations, as along with the lost talented workforce, its knowledge, relationships and previous investments in human resources in general are also lost [47].

Both reduced working hours and downsizing increase workers' feelings of job insecurity. Job insecurity is a psychological concept that reflects a subjectively perceived threat to the continuity and stability of employment [48]. Several studies have shown that the coronavirus has increased workers' perceptions of job insecurity. According to a 2020 study by the U.S. Census Bureau [49], the coronavirus epidemic has increased anxiety and depression in individuals. Choi et al. [50] examined the associations between job insecurity and financial stress and reported that job insecurity due to the coronavirus had a number of negative consequences for employees. Another study found that COVID-19-induced job insecurity also had an impact on mental well-being [51], which had a negative impact on employee mental health. It is likely that the aftermath of a coronavirus epidemic will have a significant impact on employees and thus on organizational sustainability [52]. To ensure the sustainability of organizations in the future, organizations need to be helped at the national level in the fight against the coronavirus epidemic [53].

Hypothesis H1. There is a significant relationship between the COVID-19 pandemic and the job insecurity of workers in small and medium-sized enterprises in Hungary.

The crisis has hit women, workers with disabilities and young people more deeply, as they are more vulnerable in the labor markets [54]. Women are particularly negatively affected by the supply-side and demand-side shocks of the coronavirus crisis, given their disproportionate responsibility for caring for children and sick people, and the fact that they are in most of those sectors, e.g., fashion, retail, hospitality, travel, and leisure-which initially suffered larger headcount losses [55]. According to statistical data, in the first wave of the epidemic, the employment of women in Hungary fell by $2 \%$ more than the employment of men [56]. The vulnerability of female workers is also compounded by the high proportion of female workers in low-paid jobs and the informal sector. Furthermore, female workers dominate the global supply chain workforce, which has been most affected by COVID-19 [57]. Masselot and Hayes [58] argued that although female workers have experienced some critical workplace problems in the past, including wage inequality, gender-based violence, and harassment, the pandemic has exacerbated long-standing gender inequalities. The ILO study also confirms that the COVID-19 crisis has delayed past progress in areas such as the fight against poverty, gender equality and decent work. The ILO also noted that women's employment fell by 5\% compared to men's, whose employment fell by $3.9 \%$ [36].

Hypothesis H2. The COVID-19 pandemic affected women employed in small and medium-sized enterprises in Hungary significantly more negatively than men. 


\subsection{Effect of COVID-19 on the Financial Situation of Workers}

The economic effects of the coronavirus crisis on the financial situation of workers were also significant. In addition to jobs becoming precarious and unpredictable, workers also felt financially affected by the COVID-19 crisis. In order to survive, businesses often had to deduct or reduce weekly working hours, and thus wages, and previous employee benefits. In response to the economic crisis caused by the coronavirus, the Hungarian Government announced an economic protection action plan in the spring of 2020 [59]. One of the most important government measures in Hungary was the so-called wage subsidy program and workplace protection action plan launched as part of the epidemic control, which managed to protect many Hungarian workplaces [60]. Negative opinions on the measures indicated that the amounts received were lower than previous salaries, so workers had to sacrifice part of their salary to keep their jobs. According to Jandó [61], in Hungary the government did not take over $70 \%$ of the total wage, but financed $70 \%$ of the lost working time. The maximum subsidy was limited, which was initially HUF 75,000 per employee per month. Thus, in addition to their health problems, households also had to contend with lower incomes.

Another negative criticism of the Hungarian government's measures, according to Stubnya [62], was that the payment of wage subsidies was slow, which was accompanied by an unnecessary amount of bureaucracy, so many employers received the help late, meaning that before the state program was announced, they were forced to lay off part of the workforce. The negative financial effects of the coronavirus on households are also presented in studies by Kempson and Poppe [63] and Gardiner and Slaughter [64]. According to a study by Kempson and Poppe [63], 17\% of households in the UK were in arrears in terms of housing costs, and $15 \%$ of those surveyed said they were 'struggling with the dilemma of buying food or paying for the costs'. According to Gardiner and Slaughter [64], 9 percent of people were unable to pay their rent or mortgage on time due to financial hardship caused by the coronavirus. Wilson et al. [65] reported that, in addition to job insecurity, many U.S. workers have had financial problems due to the COVID-19 pandemic. For companies, pay cuts were a common reaction in response to the COVID-19 pandemic, which severely affected U.S. workers and caused financial problems for about 49\%. According to a March 2020 survey by Statista [66], 31 percent of households in the G7 countries reported that the coronavirus had an impact on their income. Across the European Union, workers have seen a reduction in the number of hours worked per week and in many cases have been suspended, with significant redundancies in some sectors, all of which have put European households in financial difficulty. Previous research has also shown that the financial situation of Hungarian households is particularly negatively affected by crises $[67,68]$. As a result of the economic downturn due to the global financial crisis and the unfavorable labor market and income outlook, the financial burden of Hungarian households increased significantly [69].

Hypothesis H3. There is a significant relationship between the effects of the COVID-19 pandemic and the deterioration of the financial situation of employees in small and medium-sized enterprises in Hungary.

The speed with which households recover from financial problems after the health crisis is closely linked to how well households can withstand the financial shock of the coronavirus and how quickly organizations can regain and return to order before the crisis.

\section{Research Methodology}

The main aim of the research was to assess the impact of the coronavirus epidemic on the employees of small and medium-sized enterprises in Hungary. The research subobjectives included assessing the characteristics of job insecurity detected during the coronavirus epidemic and the impact of the epidemic on workers' financial situation. The method chosen to achieve the goals was a primary (questionnaire) survey, because this 
method seemed to be the easiest to implement in an epidemic situation, and it enabled researchers to easily reach a sufficient number of respondents.

Due to the epidemiological constraints and the special life situation caused by the virus, the research was carried out using a quantitative (questionnaire) research method. Sampling began in July 2021 and ended in late September.

\subsection{Study Design and Participants}

The survey was conducted in Hungary with the participation of employees in small and medium-sized enterprises. Respondents were selected using the snowball method. "Snowball sampling" is a non-probability sampling technique. During the sampling, we tried to approach other potential participants in the research through the already interviewed member of the target population. The method choice was based on the fact that the snowball sampling procedure is simple and can be used in populations that are relatively difficult to access. In the process, we first asked company executives we know, to distribute our online questionnaire to their employees. The survey thus launched was also accompanied by a significant expansion of the initial population, as we asked the initial participants to identify others who could participate in the survey. The questionnaire was created using the Google form and sent through mailing lists to approximately 2000 potential respondents. After the sampling was completed, 613 evaluable responses were returned, resulting in a response rate of 30 percent, which is moderately good. The survey was strictly anonymous and completely voluntary. The data was used for research purposes only.

The questionnaire contained a total of 22 questions. The questions were mostly answered on a 10-point Likert scale. This was important for us in the analysis, as most of the data can be extracted from it as a variable with a high measurement level. Another advantage is that a high measurement level variable can be transformed into a low measurement level variable during analyses, but vice versa it is not true. A value of 1 on the scale meant "not at all", while a value of 10 meant "fully".

The IBM SPSS.21 statistical program was used to analyze the data. Correlation analysis is used to analyze the relationship between two high-level variables (including the dummy variable), while the variance analysis compares a high and a low-level variable. The low-level (independent) variable always affects the high measurement level (dependent) variable. In determining the strength of the relationship, we generally accepted the rule that the relationship was $0.0-0.2$ weak, $0.2-0.5$ moderate and $0.5-1$ strong.

\subsection{Measures}

The explanatory variables were age, gender, position, education, number of employees and type of organization. The response variables were related to the coronavirus crisis, including the impact of the coronavirus on the body, the fear of the coronavirus, the impact of the coronavirus on workforce, changes in working conditions, changes in working methods, occupational safety, financial difficulties caused by the coronavirus, and also assessing the usefulness of government measures.

In the present research, among the variables of the questionnaire, we highlight job insecurity and the financial situation of the interviewed employees. Workplace insecurity was determined by the study of Vander Elst et al. [70]. Our statement was, "I feel insecure about my future at work". Participants had to answer on a 10-point Likert scale, from (1) I completely disagree to (10) I completely agree. A scale to measure the financial difficulty caused by COVID-19 was developed on an ad hoc basis for the present research. This scale is designed to measure existential feelings and perceptions. Respondents had to answer on a 10-point Likert scale, I completely disagree from (1) to I completely agree (10) that "my financial situation has deteriorated due to the COVID-19 crisis".

\subsection{Research Sample}

The demographic data are summarized in Table 1. Fifty-five percent of our respondents were women. In terms of age, we created 4 groups, the first group consisted of 18-25- 
year-olds (9.6\%), and the second group consisted of 26-40-year-olds, who also accounted for the largest proportion of respondents (44.9\%). The $41-55$ age group accounted for $7 \%$ of the population, while the last group included $16.2 \%$ of respondents. More than half of the respondents $(54.0 \%)$ live in cities; in the case of the other types of settlements, the respondents were roughly similar: village $(15.1 \%)$, village $(17.0 \%)$, capital $(13.5 \%)$. In terms of educational attainment, two groups are worth highlighting: $37.2 \%$ had at least a high school diploma, while more than half of the respondents, $51.7 \%$, had a university degree. More than half of the respondents $(60.7 \%)$ have been working in their current job for at least six years, of which $16.2 \%$ have been working for 10 years or more. A significant proportion of employees (88.4\%) were in full-time employment at the time of the survey.

Table 1. Profile of the sample $(n=613)$.

\begin{tabular}{|c|c|c|c|}
\hline Variable & & $\mathbf{N}$ & $\%$ \\
\hline \multirow{2}{*}{ Gender } & Male & 276 & 45.0 \\
\hline & Female & 337 & 55.0 \\
\hline \multirow{4}{*}{ Age } & 18-25 years & 59 & 9.6 \\
\hline & $26-40$ years & 275 & 44.9 \\
\hline & $41-55$ years & 227 & 7.0 \\
\hline & $56-65$ years & 52 & 16.2 \\
\hline \multirow{4}{*}{ Residence } & Village & 95 & 15.5 \\
\hline & Civil parish & 104 & 17.0 \\
\hline & City & 331 & 54.0 \\
\hline & Capital city & 83 & 13.5 \\
\hline \multirow{5}{*}{ Education } & Primary school & 8 & 1.3 \\
\hline & $\begin{array}{l}\text { High school without } \\
\text { graduation }\end{array}$ & 19 & 3.1 \\
\hline & Workman & 41 & 6.7 \\
\hline & $\begin{array}{l}\text { High school/grammar } \\
\text { school with graduation }\end{array}$ & 228 & 37.2 \\
\hline & College/university degree & 317 & 51.7 \\
\hline \multirow{4}{*}{$\begin{array}{l}\text { Number of years spent at } \\
\text { current organization }\end{array}$} & $0-2$ years & 43 & 7.0 \\
\hline & $3-5$ years & 198 & 32.3 \\
\hline & $6-9$ years & 273 & 44.5 \\
\hline & 10 years or more & 99 & 16.2 \\
\hline \multirow{2}{*}{ Employment status } & Part time & 71 & 11.6 \\
\hline & Full time & 542 & 88.4 \\
\hline Total & & 613 & 100.0 \\
\hline
\end{tabular}

\section{Results}

During the assessment of job insecurity, we examined our variables by analysis of variance. Here, we examined the relationship between a high and a low level variable. Most of our questions were Likert-scale questions ranging from 1 to 10 . We divided our high-level variables into 3 parts according to the measurement, thus creating a low-level variable. The 3 parts were not determined in equal proportions, but in the ascending order of the scale, the first three values formed the first group, the 4-7 values the second, and the others the third group. It follows that there were large differences between the categories of our low-level variables. Thus, we had to examine normality as a condition, which was fulfilled in both cases. The next condition will be to check the homogeneity of variance, which is realized during the analysis. Depending on whether this was done, we ran the Hochberg's GT2 test (large differences for the low-level variable), while the Games-Howell test was used if the condition was violated.

In testing our first hypothesis, when we examined the relationship between headcount reduction due to the COVID-19 and job insecurity, the homogeneity of variance was impaired $(p=0.000)$, with a mean job insecurity of 5.81. Consequently, we looked at the 
relationship using the Welch test, which showed a significant relationship between the two variables. The strength of the relationship was $r=0.43$. Thus, the reduction in headcount caused by the virus had an effect on the feeling of safety at work of the workers interviewed. Where the number of employees in the organization was not reduced or slightly reduced, the average job insecurity was 5.09 , in the case of a moderate downsizing the value was 6.88 and where there was a significant downsizing, the result was a high job insecurity of 7.84. Table 2 shows the result of the descriptive analysis.

Table 2. Descriptive Statistic.

\begin{tabular}{|c|c|c|c|c|c|c|c|c|}
\hline & \multirow[t]{2}{*}{$\mathbf{N}$} & \multirow[t]{2}{*}{ Mean } & \multirow{2}{*}{$\begin{array}{c}\text { Std. } \\
\text { Deviation }\end{array}$} & \multirow{2}{*}{$\begin{array}{l}\text { Std. } \\
\text { Error }\end{array}$} & \multicolumn{2}{|c|}{$\begin{array}{l}95 \% \text { Confidence } \\
\text { Interval for Mean }\end{array}$} & \multirow[t]{2}{*}{ Minimum } & \multirow[t]{2}{*}{ Maximum } \\
\hline & & & & & $\begin{array}{l}\text { Lower } \\
\text { Bound }\end{array}$ & $\begin{array}{l}\text { Upper } \\
\text { Bound }\end{array}$ & & \\
\hline $\begin{array}{l}\text { Due to the COVID- } 19 \\
\text { pandemic, the organization } \\
\text { has not been downsized at all } \\
\text { or in a small compass. }\end{array}$ & 428 & 5.09 & 2509 & 0.121 & 4.86 & 5.33 & 1 & 10 \\
\hline $\begin{array}{l}\text { Due to the COVID- } 19 \\
\text { pandemic, the organization } \\
\text { has been moderately } \\
\text { downsized. }\end{array}$ & 72 & 6.88 & 2.489 & 0.293 & 6.29 & 7.46 & 2 & 10 \\
\hline $\begin{array}{l}\text { Due to the COVID- } 19 \\
\text { pandemic, the organization } \\
\text { has been significantly } \\
\text { downsized. }\end{array}$ & 113 & 7.84 & 1.590 & 0.150 & 7.54 & 8.14 & 5 & 10 \\
\hline Total & 613 & 5.81 & 2.613 & 0.106 & 5.60 & 6.02 & 1 & 10 \\
\hline
\end{tabular}

Based on the significance level, it can be said that there is a significant difference between the groups. Where there was a small reduction in the size of the body, respondents thought on average 2747 in absolute terms that the virus had less of an impact on their lives than a significant reduction in the size of the body $(p=0.000$, standard error $=0.193)$. Based on the results, the more staff members were reduced, the more job insecurity was experienced. This was also supported by significant differences between groups. Based on these, we accept our hypothesis 1 , according to which there is a significant relationship between the effect of the coronavirus and job insecurity in the case of small and mediumsized enterprises in Hungary. The result of the Welch test, which is reported in Table 3, clearly shows that there is a significant difference among the means, and we proceed with the results of Games-Howell test, which is presented in Table 4.

Table 3. Welch robust test of equality of means.

\begin{tabular}{ccccc}
\hline & Statistic $^{\text {a }}$ & df1 & df2 & Sig. \\
\hline Job insecurity & 103,881 & 2 & 169,673 & 0.000 \\
\hline Note. $^{\text {a }}$. Asymptotically F distributed. & & &
\end{tabular}

In the second hypothesis test, we searched for a relationship between "gender" and "COVID-19 pandemic effect" variables. The first variable is a dummy variable, since there are 2 outcomes, the male and female, and the other variables are Likert-scale variables. Consequently, Pearson's correlation analysis was performed first, with a significance level of $p=0.175$, suggesting that there was no significant relationship. Thus, hypothesis 2 is rejected. 
Table 4. Games-Howell test for phase-wise comparison among the means.

\begin{tabular}{|c|c|c|c|c|c|c|}
\hline & & \multirow{2}{*}{$\begin{array}{c}\text { Mean } \\
\text { Difference }\end{array}$} & \multirow[b]{2}{*}{ Std. Error } & \multirow{2}{*}{ Sig. } & \multicolumn{2}{|c|}{ 95\% Confidence Interval } \\
\hline & & & & & Lower Bound & Upper Bound \\
\hline \multirow{2}{*}{$\begin{array}{l}\text { Not at all or in a small } \\
\text { compass }\end{array}$} & Moderately & $-1782 *$ & 0.317 & 0.000 & -2.54 & -1.03 \\
\hline & Significantly & $-2747^{*}$ & 0.193 & 0.000 & -3.20 & -2.29 \\
\hline \multirow{2}{*}{ Moderately } & $\begin{array}{l}\text { Not at all or in a } \\
\text { small compass }\end{array}$ & $1782 *$ & 0.317 & 0.000 & 1.03 & 2.54 \\
\hline & Significantly & $-966^{*}$ & 0.329 & 0.011 & -1.75 & -0.18 \\
\hline \multirow[t]{2}{*}{ Significantly } & $\begin{array}{l}\text { Not at all or in a } \\
\text { small compass }\end{array}$ & $2747 *$ & 0.193 & 0.000 & 2.29 & 3.20 \\
\hline & Moderately & $966^{*}$ & 0.329 & 0.011 & 0.18 & 1.75 \\
\hline
\end{tabular}

Note. ${ }^{*}$ The mean difference is significant at the 0.05 level.

In the course of our hypothesis 3 study, we sought the answer to the fact if there is a significant relationship between the COVID-19 and the financial problems of Hungarian employees. Similar to the first hypothesis test, the homogeneity of variance was impaired here as well, so we looked at the result of the Welch test, which showed a significant relationship between the two variables (COVID-19 epidemic and employee financial problems). The strength of the relationship is $r=0.62$, which shows a strong relationship. It can be said that the more one perceived the effects of the epidemic, the greater the financial problems caused to him by COVID-19. There was also a significant difference between the groups. Those who were least affected by the epidemic were less affected by the financial problem, with candidates averaging 2.79 . Those moderately affected by the COVID-19 pandemic face an average of 4.95 financial problems. Where COVID-19 had a significant impact, our respondents rated their perceived financial problems on average 8.05. Table 5 shows the result of the descriptive analysis.

Table 5. Descriptive Statistic.

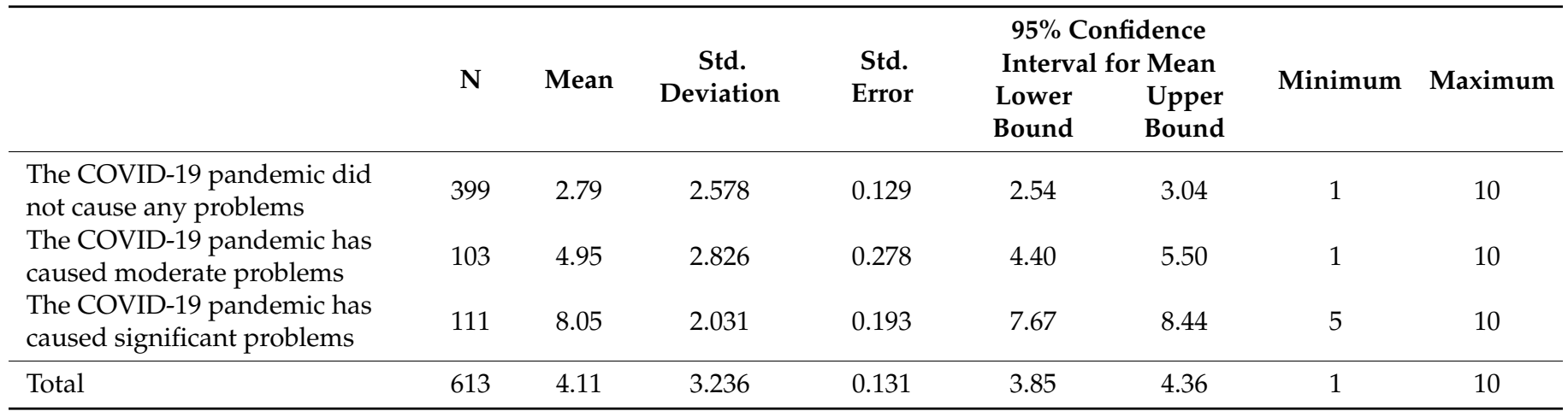

Those who did not perceive it at all and who were very aware of the financial consequences of the COVID-19 epidemic had an average deviation of 5265 in absolute terms $(p=0.000$, standard error $=0.232)$. We then compared the relationship between the mild and moderate impact of the epidemic $(p=0.000$, standard error $=0.307)$, so there was a significant difference between the two values, with an absolute value of 2.162 for the financial problem. There was an average difference of 3103 absolute values between the medium and high epidemic effects $(p=0.000$, standard error $=0.339)$. Based on these, it can be concluded that the more someone was affected by the COVID-19 epidemic, the more he/she had a financial problem. Based on these, we accept our hypothesis 3, according to which there is a significant relationship between the effect of coronavirus and the financial problems of the employees employed in the interviewed small and medium-sized enterprises. The result of the Welch test, which is reported in Table 6, clearly shows that there is a significant difference among the means, we proceed with the results of Games-Howell test which is presented in Table 7. 
Table 6. Welch robust test of equality of means.

\begin{tabular}{lcccc}
\hline & Statistic $^{\text {a }}$ & df1 & df2 & Sig. \\
\hline Financial problems of the employees & 258,319 & 2 & 210,207 & 0.000 \\
\hline Note. $^{\text {a }}$ Asymptotically F distributed. & &
\end{tabular}

Note. ${ }^{a}$ Asymptotically F distributed.

Table 7. Games-Howell test for phase-wise comparison among the means.

\begin{tabular}{lcccccc}
\hline & & $\begin{array}{c}\text { Mean } \\
\text { Difference }\end{array}$ & $\begin{array}{c}\text { Std. } \\
\text { Error }\end{array}$ & Sig. & \multicolumn{2}{c}{$\begin{array}{c}\text { 95\% Confidence Interval } \\
\text { Lower Bound } \\
\text { Upper Bound }\end{array}$} \\
\hline It caused almost no & It caused moderate problems & $-2162^{*}$ & 0.307 & 0.000 & -2.89 & -1.44 \\
problem at all & It caused significant problems & $-5265^{*}$ & 0.232 & 0.000 & -5.81 & -4.72 \\
\hline It caused moderate & It caused almost no problem at all & $2162^{*}$ & 0.307 & 0.000 & 1.44 & 2.89 \\
problems & It caused significant problems & $-3103^{*}$ & 0.339 & 0.000 & -3.90 & -2.30 \\
\hline It caused significant & It caused almost no problem at all & $5265^{*}$ & 0.232 & 0.000 & 4.72 & 5.81 \\
problems & It caused moderate problems & $3103^{*}$ & 0.339 & 0.000 & 2.30 & 3.90 \\
\hline
\end{tabular}

Note. * The mean difference is significant at the 0.05 level.

\section{Discussion}

This study examined the job insecurity, financial difficulties and their correlations related to COVID-19 among employees in Hungarian small and medium-sized enterprises during the pandemic.

Workplace security can be defined as the psychological state of employees that is related to their expectations of foreseeable future work processes [71]. There are a number of key elements to job insecurity, such as experiencing a perceived threat and the feeling that your work conditions and safety are at risk [72]. Most researchers treat workplace safety as a subjective, perceptual variable based on environmental signals [73,74]. During the COVID-19 epidemic, employees perceived that their jobs were precarious due to internal pressures, such as declining demand, supply chain problems or the organizational effects of strict epidemiological measures [75]. In addition, external factors, such as political, economic and/or social problems can also pose a risk to workers' jobs [76,77].

In the case of the examined Hungarian employees, the feeling of job insecurity was generally observed. This finding is confirmed by a number of international studies that have shown similar relationships between the coronavirus crisis and feelings of job insecurity $[78,79]$. Feelings of insecurity were affected by fears of losing their jobs, as workers with higher levels of redundancy due to the coronavirus crisis also had higher feelings of insecurity [80-82]. Another factor that reinforced the uncertainty was that most of the workers surveyed faced financial difficulties due to the COVID-19 crisis. The measures introduced due to the coronavirus also had an impact on the financial situation of the companies, so that it continued to have a negative effect on the financial situation of the respondents. Our research is confirmed by a number of international studies, which show that the financial shock caused by the coronavirus has a long-term effect [83], regardless of the income level of households, and weakens the financial security of households $[84,85]$. It should also be borne in mind that the consequences of the current wave could lead to job losses or loss of pay for many people, so that their savings could fall rapidly or even completely. The above negative feelings can have a long-term economic impact on both people and individual societies. Because of the uncertainty and fear of the virus, people's lives are being transformed, they are spending less and less and the economy will not be able to return to its previous level of development.

Gender equality is one of the UN's Sustainable Development Goals [86], which emphasizes the full participation of men and women in economic and political life. Therefore, our second research question was about the impact of the pandemic on the situation of women and men on the Hungarian labor market. The COVID-19 pandemic is having a strong impact on sectors with a high female employment rate worldwide. The hypothesis 
that the pandemic affected the labor market situation of women more negatively than that of men has not been confirmed in the case of Hungary.

\section{Conclusions}

The outbreak of COVID-19 had severe global consequences, not only from a health point of view, but also from a social and economic point of view. The present research has shown that the coronavirus epidemic also has an impact on job insecurity and the financial problems of workers. The pandemic has prompted many organizations to transform their operations in a short period of time [11]. As a result, the sustainability of organizations can change significantly. In the future, organizations must be prepared for sudden, unpredictable crises so that the continuity of organizational operations is not jeopardized. Retaining a quality workforce is important for organizations to operate sustainably and efficiently [87], but they may need a quick solution to reduce job insecurity and eliminate financial problems. During the epidemic, most of the organizations have tried to learn from each other and adopt the best practices, a process that can make organizations and employees more resilient and create long-term sustainable work models and solutions [88].

The COVID19 pandemic caused a huge setback in world economic processes, which also brought about changes in employment and labor market processes. The re-emergence, prolongation and severity of the epidemic, as well as the government's responses to them, have a significant impact on the development of economic processes, including the employment situation. As a result, a number of risk factors continue to threaten labor market actors and need to be addressed at both governmental and corporate levels. Governments of nations need to provide additional financial support to companies to avoid layoffs. They should also support vulnerable workers (women, young people, people with disabilities) who have been severely affected by the COVID-19 pandemic.

In addition, employers need to be better prepared for future crises, regularly assess changes in the environment and have a contingency plan in place to respond to them. The present study makes a significant contribution to the enrichment of the literature by filling in the gaps, as it helps those interested in the topic to understand the effects of the COVID-19 epidemic on small and medium-sized enterprises in Hungary. Regarding the limitations of the study, it should be mentioned that our results are country-specific, so it would be worthwhile to extend our studies to other countries in order to properly assess the impact of COVID-19 on the labor market.

\section{Limitations of the Study and Possible Future Research Directions}

The present study has several research limitations. The first such research limitation is that the survey only covered small and medium-sized enterprises in Hungary, so no global conclusions can be drawn from the results obtained. Another research limitation is that the study does not take into account sectoral differences. One of the main reasons for this was that no statistical correlations could be established for each sector on the basis of the sample obtained. Although it is true that the coronavirus epidemic had a different impact on each sector, the main aim of this study was not to assess the sectoral effects, but to examine in general the impact of the coronavirus epidemic on the job insecurity and financial situation of Hungarian SMEs. The third limitation is that the sample cannot be considered representative, as in Hungary, according to the data of the Central Statistical Office, there are approximately 785,000 small and medium-sized enterprises, and a total of 720 of them were contacted, where almost 2000 questionnaires were distributed, of which 613 evaluable responses were returned. However, the strength of the study is given by the novelty of the chosen topic and the fact that the present study fills a gap, as no comprehensive study of the job insecurity and financial situation of employees of Hungarian small and medium-sized enterprises has been conducted to date. Therefore, despite the limitations, the study may serve as a useful reference for future research.

Of the future research directions, those based on the evaluation of primary data collected at the sectoral level may be important, thus helping to better understand the 
economic impact of the pandemic. Future research may gather data from different sectors from well-defined contexts to test the results presented here. Furthermore, as the focus of this study was on small and medium-sized enterprises in Hungary, it is worthwhile to conduct future research internationally, and the data obtained can be analyzed and compared internationally, which may help to better understand the national and global economic impacts of COVID-19.

Author Contributions: P.K., K.K. and I.A. contributed equally to this work. All authors contributed to the conceptualization, formal analysis, investigation, methodology, writing of the original draft and review and editing. All authors have read and agreed to the published version of the manuscript.

Funding: This research was funded by the Pallas Athéné Foundations.

Institutional Review Board Statement: This research was approved by the Institutional Review Board at Faculty of Economics and Informatics of J. Selye University (protocol number IRB-2-2021).

Informed Consent Statement: Informed consent was obtained from all subjects involved in the study.

Data Availability Statement: The data presented in this study are available on request from the correspondent author.

Conflicts of Interest: The authors declare no conflict of interest.

\section{References}

1. Amara, S.A.; Díaz, E.D.; Menon, L.K.; Singh, P.; Rozanova, L.; Flahault, A. COVID-19 Outbreak Management and Vaccination Strategy in The United States of America. Epidemiologia 2021, 10, 426-453. Available online: https://doi.org/10.3390/ epidemiologia2030031 (accessed on 17 December 2021).

2. Worldometer. Coronavirus Updates. Available online: https://www.worldometers.info/coronavirus/ (accessed on 17 December 2021).

3. Walach, H.; Klement, R.J.; Aukema, W. The Safety of COVID-19 Vaccinations-We Should Rethink the Policy. Vaccines 2021, 9 , 693. [CrossRef] [PubMed]

4. Seing, I.; Thórný Stefánsdóttir, N.; Wassar Kirk, J.; Andersen, O.; Tjørnhøj-Thomsen, T.; Kallemose, T.; Vedung, E.; Vrangbæk, K.; Nilsen, P. Social Distancing Policies in the Coronavirus Battle: A Comparison of Denmark and Sweden. Int. J. Environ. Res. Public Health 2021, 18, 10990. [CrossRef]

5. $\mathrm{Su}, \mathrm{Z}$. Rigorous Policy-Making Amid COVID-19 and Beyond: Literature Review and Critical Insights. Int. J. Environ. Res. Public Health 2021, 18, 12447. [CrossRef] [PubMed]

6. Duan, T.; Sun, Z.; Shi, G. Sustained Effects of Government Response on the COVID-19 Infection Rate in China: A Multiple Mediation Analysis. Int. J. Environ. Res. Public Health 2021, 18, 12422. [CrossRef]

7. Chisadza, C.; Clance, M.; Gupta, R. Government Effectiveness and the COVID-19 Pandemic. Sustainability 2021, 13, 3042. [CrossRef]

8. Wang, R. Measuring the Effect of Government Response on COVID-19 Pandemic: Empirical Evidence from Japan. COVID 2021, 1, 276-287. [CrossRef]

9. Kerekes, S.; Badea, A.G.-E.; Paun, D. Analyzing Lockdown Policies and Their Effectiveness in Romania and Hungary. Challenges 2021, 12, 20. [CrossRef]

10. Mohr, A.K.; Laemmer, C.; Schulte, S.; Gohlke, B. Effects of COVID-19 Lockdown on Weight, Body Composition, and Behavior of Children, Adolescents, and Young Adults with Prader-Willi Syndrome. J. Clin. Med. 2021, 10, 4746. [CrossRef]

11. Ng, M.A.; Naranjo, A.; Schlotzhauer, A.E.; Shoss, M.K.; Kartvelishvili, N.; Bartek, M.; Ingraham, K.; Rodriguez, A.; Schneider, S.K.; Silverlieb-Seltzer, L.; et al. Has the COVID-19 Pandemic Accelerated the Future of Work or Changed Its Course? Implications for Research and Practice. Int. J. Environ. Res. Public Health 2021, 18, 10199. [CrossRef]

12. Pfeifer, M.R. Human Resources during COVID-19: A Monthly Survey on Mental Health and Working Attitudes of Czech Employees and Managers during the Year 2020. Sustainability 2021, 13, 10055. [CrossRef]

13. Ramaci, T.; Pagliaro, S.; Teresi, M.; Barattucci, M. Job Demands and Negative Outcomes after the Lockdown: The Moderating Role of Stigma towards Italian Supermarket Workers. Sustainability 2021, 13, 7507. [CrossRef]

14. Matisane, L.; Paegle, L.; Akulova, L.; Vanadziňš, I. Challenges for Workplace Risk Assessment in Home Offices—Results from a Qualitative Descriptive Study on Working Life during the First Wave of the COVID-19 Pandemic in Latvia. Int. J. Environ. Res. Public Health 2021, 18, 10876. [CrossRef] [PubMed]

15. Rachmawati, R.; Choirunnisa, U.; Pambagyo, Z.A.; Syarafina, Y.A.; Ghiffari, R.A. Work from Home and the Use of ICT during the COVID-19 Pandemic in Indonesia and Its Impact on Cities in the Future. Sustainability 2021, 13, 6760. [CrossRef]

16. Koohsari, M.J.; Nakaya, T.; Shibata, A.; Ishii, K.; Oka, K. Working from Home After the COVID-19 Pandemic: Do Company Employees Sit More and Move Less? Sustainability 2021, 13, 939. [CrossRef] 
17. Ipsen, C.; van Veldhoven, M.; Kirchner, K.; Hansen, J.P. Six Key Advantages and Disadvantages of Working from Home in Europe during COVID-19. Int. J. Environ. Res. Public Health 2021, 18, 1826. [CrossRef]

18. Karácsony, P. Impact of teleworking on job satisfaction among Slovakian employees in the era of COVID-19. Probl. Perspect. Manag. 2021, 19, 1-9. [CrossRef]

19. Raghavan, A.; Demircioglu, M.A.; Orazgaliyev, S. COVID-19 and the New Normal of Organizations and Employees: An Overview. Sustainability 2021, 13, 11942. [CrossRef]

20. Loia, F.; Adinolfi, P. Teleworking as an Eco-Innovation for Sustainable Development: Assessing Collective Perceptions during COVID-19. Sustainability 2021, 13, 4823. [CrossRef]

21. Rodousakis, N.; Soklis, G. The Impact of COVID-19 on the US Economy: The Multiplier Effects of Tourism. Economies 2022, 10, 2. [CrossRef]

22. Barlow, J.; Vodenska, I. Socio-Economic Impact of the COVID-19 Pandemic in the U.S. Entropy 2021, 23, 673. [CrossRef] [PubMed]

23. Jabłońska, M.R.; Zajdel, K.; Zajdel, R. Social and Psychological Consequences of COVID-19 Online Content at a Lockdown Phase-Europe and Asia Comparison. Sustainability 2021, 13, 9198. [CrossRef]

24. Kim, J.; Kim, Y.; Ha, J. Changes in Daily Life during the COVID-19 Pandemic among South Korean Older Adults with Chronic Diseases: A Qualitative Study. Int. J. Environ. Res. Public Health 2021, 18, 6781. [CrossRef] [PubMed]

25. Algahtani, F.D.; Hassan, S.-u.-N.; Alsaif, B.; Zrieq, R. Assessment of the Quality of Life during COVID-19 Pandemic: A CrossSectional Survey from the Kingdom of Saudi Arabia. Int. J. Environ. Res. Public Health 2021, 18, 847. [CrossRef]

26. Salazar, A.; Palomo-Osuna, J.; de Sola, H.; Moral-Munoz, J.A.; Dueñas, M.; Failde, I. Psychological Impact of the Lockdown Due to the COVID-19 Pandemic in University Workers: Factors Related to Stress, Anxiety, and Depression. Int. J. Environ. Res. Public Health 2021, 18, 4367. [CrossRef]

27. Chand, S.; Yee, E.; Alsultan, A.; Dixit, V.V. A Descriptive Analysis on the Impact of COVID-19 Lockdowns on Road Traffic Incidents in Sydney, Australia. Int. J. Environ. Res. Public Health 2021, 18, 11701. [CrossRef]

28. CNBC. Here are Key Ways the Coronavirus Crisis Differs from the Great Recession. Available online: https://www.cnbc.com/20 20/05/27/here-are-key-ways-coronavirus-crisis-differs-from-the-great-recession.html (accessed on 20 December 2021).

29. Sane Schepisi, M.; di Napoli, A.; Asciutto, R.; Vecchi, S.; Mirisola, C.; Petrelli, A. The 2008 Financial Crisis and Changes in Lifestyle-Related Behaviors in Italy, Greece, Spain, and Portugal: A Systematic Review. Int. J. Environ. Res. Public Health 2021, 18, 8734. [CrossRef]

30. Li, Z.; Farmanesh, P.; Kirikkaleli, D.; Itani, R. A comparative analysis of COVID-19 and global financial crises: Evidence from US economy. Econ. Res. Ekon. Istraživanja 2021, 1, 1-15. [CrossRef]

31. Rietveld, J.R.; Hiemstra, D.; Brouwer, A.E.; Waalkens, J. Motivation and Productivity of Employees in Higher Education during the First Lockdown. Adm. Sci. 2022, 12, 1. [CrossRef]

32. Rožman, M.; Peša, A.; Rajko, M.; Štrukelj, T. Building Organisational Sustainability during the COVID-19 Pandemic with an Inspiring Work Environment. Sustainability 2021, 13, 11747. [CrossRef]

33. Vinerean, S.; Opreana, A.; Tileagă, C.; Popșa, R.E. The Impact of COVID-19 Pandemic on Residents' Support for Sustainable Tourism Development. Sustainability 2021, 13, 12541. [CrossRef]

34. Khan, K.I.; Niazi, A.; Nasir, A.; Hussain, M.; Khan, M.I. The Effect of COVID-19 on the Hospitality Industry: The Implication for Open Innovation. J. Open Innov. Technol. Mark. Complex. 2021, 7, 30. [CrossRef]

35. Sun, J.; Lee, H.; Yang, J. The Impact of the COVID-19 Pandemic on the Global Value Chain of the Manufacturing Industry. Sustainability 2021, 13, 12370. [CrossRef]

36. ILO. ILO Monitor: COVID-19 and the World of Work. Seventh Edition Updated Estimates and Analysis. Available online: https://www.ilo.org/wcmsp5/groups/public/---dgreports/---dcomm/documents/briefingnote/wcms_767028.pdf (accessed on 20 December 2021).

37. ILO. ILO Monitor: COVID-19 and the World of Work. Second Edition Updated Estimates and Analysis. Available online: https://www.ilo.org/wcmsp5/groups/public/---dgreports/---dcomm/documents/briefingnote/wcms_740877.pdf (accessed on 20 December 2021).

38. Saif, N.M.A.; Ruan, J.; Obrenovic, B. Sustaining Trade during COVID-19 Pandemic: Establishing a Conceptual Model Including COVID-19 Impact. Sustainability 2021, 13, 5418. [CrossRef]

39. Chahuán-Jiménez, K.; Rubilar-Torrealba, R.; de la Fuente-Mella, H. Market Openness and Its Relationship to Connecting Markets Due to COVID-19. Sustainability 2021, 13, 10964. [CrossRef]

40. Raimo, N.; MartínezCórdoba, P.-J.; Benito, B.; Vitolla, F. The Impact of the COVID-19 Pandemic on the Labor Market: An Analysis of Supply and Demand in the Spanish Municipalities. Sustainability 2021, 13, 12996. [CrossRef]

41. Brinca, P.; Duarte, J.B.; Faria-e-Castro, M. Measuring labor supply and demand shocks during COVID-19. Eur. Econ. Rev. 2021, 139, 103901. [CrossRef] [PubMed]

42. Siuta-Tokarska, B. SMEs during the COVID-19 Pandemic Crisis. The Sources of Problems, the Effects of Changes, Applied Tools and Management Strategies-The Example of Poland. Sustainability 2021, 13, 185. [CrossRef]

43. European Parliament. Impacts of the COVID-19 Pandemic on EU Industries. Available online: https://www.europarl.europa.eu/ RegData/etudes/STUD/2021/662903/IPOL_STU(2021)662903_EN.pdf (accessed on 21 December 2021).

44. Araújo-Vila, N.; Fraiz-Brea, J.A.; Pereira, A.M. Societal Changes Due to "COVID-19". An Analysis of the Tourism Sector of Galicia, Spain. Sustainability 2021, 13, 8449. [CrossRef] 
45. Li, B.; Fan, X.; Álvarez-Otero, S.; Sial, M.S.; Comite, U.; Cherian, J.; Vasa, L. CSR and Workplace Autonomy as Enablers of Workplace Innovation in SMEs through Employees: Extending the Boundary Conditions of Self-Determination Theory. Sustainability 2021, 13, 6104. [CrossRef]

46. Béres, R. A munkanélküliség lélektani háttere—az újrakezdés esélye vagy a megrekedés veszélye? Metszetek 2012, 4, 181-202.

47. Héder, M. Munkaerő- vagy tehetséghiány?-Fogalmi különbségek feltárása a hatékony gyakorlati alkalmazás érdekében. Labouror talent shortage?-Exploring the conceptual differences for effective practice. Int. J. Eng. Manag. Sci. 2017, 181-190. [CrossRef]

48. Shoss, M.K. Job Insecurity: An Integrative Review and Agenda for Future Research. J. Manag. 2017, 43, 1911-1939. [CrossRef]

49. U.S. Census Bureau. Household Pulse Survey. Available online: https://www.cdc.gov/nchs/covid19/pulse/mental-health.html (accessed on 21 December 2021).

50. Choi, S.L.; Heo, W.; Cho, S.H.; Lee, P. The links between job insecurity, financial well-being and financial stress: A moderated mediation model. Int. J. Cons. Stud. 2020, 44, 353-360. [CrossRef]

51. Sarwar, A.; Maqsood, U.; Mujtaba, B.G. Impact of Job Insecurity due to COVID-19 on the Psychological Wellbeing and Resiliency of Food Delivery Personnel. Int. J. Hum. Resour. Stud. 2020, 11, 1-24. [CrossRef]

52. Lee, H.-W.; Rhee, D.-Y. Exploring the Factors of Employee Subjective Well-Being in the Midst of Health Threat: An Evidence from the U.S. Federal Government during the COVID-19. Sustainability 2022, 14, 408. [CrossRef]

53. Bojnec, Š.; Žampa, S. Subsidies and Economic and Financial Performance of Enterprises. J. Risk Financial Manag. 2021, 14, 505. [CrossRef]

54. Krywult-Albanska, M.; Albanski, Ł. Gender and Educational Inequalities during the COVID-19 Pandemic: Preliminary Insights from Poland. Sustainability 2021, 13, 12403. [CrossRef]

55. Carranza, E.; Farole, T.; Gentilini, U.; Morgandi, M.; Packard, T.; Santos, I.; Weber, M. Managing the Employment Impacts of the COVID-19 Crisis: Policy Options for Relief and Restructuring. Jobs Working Paper; No. 49; World Bank: Washington, DC, USA, 2020. Available online: https:/ / openknowledge.worldbank.org/handle/10986/34263 (accessed on 21 December 2021).

56. Köllő, J. Foglalkoztatás a koronavírus-járvány első hullámának idején. In Munkaerőpiaci Tükör 2019; Munkaerőpiaci Tükör, Közgazdaság—és Regionális Tudományi Kutatóközpont: Budapest, Hungary, 2020; pp. 220-232. Available online: https: / / kti.krtk.hu/wp-content/uploads/2020/12/mt_2019_220-232.pdf (accessed on 21 January 2022).

57. Jalan, S. What COVID-19 Means for Women in Global Supply Chains-And How Companies Can Take Action. 2020. Available online: https://unfoundation.org/blog/post/what-covid-19-means-for-women-in-global-supply-chains-and-how-companiescan-take-action/ (accessed on 22 December 2021).

58. Masselot, A.; Hayes, M. Exposing Gender Inequalities: Impacts of COVID-19 on Aotearoa New Zealand Employment. N. Z. J. Employ. Relat. 2020, 45, 57-69. [CrossRef]

59. Hungary Today. Coronavirus: Orbán Presents 5-point Economic Protection Plan, Announces Extra 13th Month Pension. Available online: https:/ / hungarytoday.hu/coronavirus-orban-economic-protection-plan-extra-pension (accessed on 22 December 2021).

60. Tóth, A.; Kálmán, B.; Poór, J. Employment in Hungarian economy as a result of the COVID-19 pandemic. Acta Oeconomica Univ. Selye 2021, 10, 84-96. [CrossRef]

61. Jandó, Z. Közelében Sincs a 70 Százaléknak a Kormány Nagy Bérátvállalása, és ez Nagy Baj. 2020. Available online: https: //g7.hu/vallalat/20200415/kozeleben-sincs-a-70-szazaleknak-a-kormany-nagy-beratvallalasa-es-ez-nagy-baj (accessed on 12 December 2021).

62. Stubnya, B. Egy Hét Után Máris Barkácsolni Kell a Munkahelyvédő Programot, de Miért Lett Ennyire Szúkmarkú? 2020. Available online: https:/ /g7.hu/ kozelet/20200421/egy-het-utan-maris-barkacsolni-kell-a-munkahelyvedo-programot-de-miertlett-ennyire-szukmarku (accessed on 20 December 2021).

63. Kempson, E.; Poppe, C. Coronavirus Financial Impact Tracker. Standard Life Foundation. 2020. Available online: https: / / www.standardlifefoundation.org.uk/our-work/coronavirus-finance-tracker2/coronavirus-financetracker/ (accessed on 20 December 2021).

64. Gardiner, L.; Slaughter, H. The Effects of the Coronavirus Crisis on Workers. Resolution Foundation. 2020. Available online: https:/ / www.resolutionfoundation.org/app/uploads/2020/05/The-effect-of-the-coronavirus-crisis-onworkers.pdf (accessed on 20 December 2021).

65. Wilson, J.M.; Lee, J.; Fitzgerald, H.N.; Oosterhoff, B.; Sevi, B.; Shook, N.J. Job Insecurity and Financial Concern During the COVID-19 Pandemic Are Associated With Worse Mental Health. J. Occup. Environ. Med. 2020, 62, 686-691. [CrossRef] [PubMed]

66. Statista. Opinion of Adults in G7 Countries of the Expected Impact of the COVID-19 Pandemic on Their Household Income as of March 2020. Available online: https:/ / www.statista.com/statistics/1107322/covid-19-expected-impact-household-income-g7 (accessed on 20 December 2021).

67. Kocziszky, G.; Benedek, J.; Szendi, D. The impact of the 2008 financial crisis on household income and wealth in Visegrad countries. Reg. Stat. 2018, 8, 141-167. [CrossRef]

68. Atanaszov, D.; Barczikay, T. A 2008-as pénzügyi válság hatása a magyarországi kereskedelmi bankok mérlegadatainak tükrében. Köz-Gazdaság Rev. Econ. Theory Policy 2020, 12, 17-36.

69. Boldizsár, A.; Kékesi, Z.; Kóczián, B.; Sisak, B. A Magyar háztartások vagyoni helyzete a HFCS felmérés alapján. Hitelintézeti Szle 2016, 15, 115-150.

70. Vander, T.E.; de Witte, H.; de Cuyper, N. The Job Insecurity Scale: A psychometric evaluation across five European countries. Eur. J. Work Organ. Psychol. 2014, 23, 364-380. [CrossRef] 
71. Stankeviciute, Ž.; Staniškiene, E.; Ramanauskaite, J. The Impact of Job Insecurity on Organisational Citizenship Behaviour and Task Performance: Evidence from Robotised Furniture Sector Companies. Int. J. Environ. Res. Public Health 2021, 18, 515. [CrossRef]

72. Jiang, L.; Lavaysse, L.M. Cognitive and Affective Job Insecurity: A Meta-Analysis and a Primary Study. J. Manag. 2018, 44, 2307-2342. [CrossRef]

73. De Cuyper, N.; Notelaers, G.; de Witte, H. Job insecurity and employability in fixed-term contractors, agency workers, and permanent workers: Associations with job satisfaction and affective organizational commitment. J. Occup. Health Psychol. 2009, 14, 193-205. [CrossRef]

74. Giunchi, M.; Vonthron, A.-M.; Ghislieri, C. Perceived Job Insecurity and Sustainable Wellbeing: Do Coping Strategies Help? Sustainability 2019, 11, 784. [CrossRef]

75. Elshaer, I.A.; Azazz, A.M.S. Amid the COVID-19 Pandemic, Unethical Behavior in the Name of the Company: The Role of Job Insecurity, Job Embeddedness, and Turnover Intention. Int. J. Environ. Res. Public Health 2022, 19, 247. [CrossRef]

76. Chirumbolo, A.; Callea, A.; Urbini, F. The Effect of Job Insecurity and Life Uncertainty on Everyday Consumptions and Broader Life Projects during COVID-19 Pandemic. Int. J. Environ. Res. Public Health 2021, 18, 5363. [CrossRef] [PubMed]

77. Kalleberg, A.L. Job Insecurity and Well-Being in Rich Democracies. Econ. Soc. Rev. 2018, 49, 241-258. Available online: https:/ / www.esri.ie/pubs/gls47.pdf (accessed on 20 December 2021).

78. Maleki, M.; Mardani, A.; Vaismoradi, M. Insecure Employment Contracts during the COVID-19 Pandemic and the Need for Participation in Policy Making. Int. J. Environ. Res. Public Health 2021, 18, 12548. [CrossRef] [PubMed]

79. Yiwen, F.; Hahn, J. Job Insecurity in the COVID-19 Pandemic on Counterproductive Work Behavior of Millennials: A Time-Lagged Mediated and Moderated Model. Int. J. Environ. Res. Public Health 2021, 18, 8354. [CrossRef] [PubMed]

80. Lippert, J.F.; Furnari, M.B.; Kriebel, C.W. The Impact of the COVID-19 Pandemic on Occupational Stress in Restaurant Work: A Qualitative Study. Int. J. Environ. Res. Public Health 2021, 18, 10378. [CrossRef]

81. Giorgi, G.; Lecca, L.I.; Alessio, F.; Finstad, G.L.; Bondanini, G.; Lulli, L.G.; Arcangeli, G.; Mucci, N. COVID-19-Related Mental Health Effects in the Workplace: A Narrative Review. Int. J. Environ. Res. Public Health 2020, 17, 7857. [CrossRef] [PubMed]

82. Bazzoli, A.; Probst, T.M.; Lee, H.J. Economic Stressors, COVID-19 Attitudes, Worry, and Behaviors among U.S. Working Adults: A Mixture Analysis. Int. J. Environ. Res. Public Health 2021, 18, 2338. [CrossRef]

83. Nasir, H.; Navel, V.; Baker, J.S.; Supriya, R.; Cole, A.; Gao, Y.; Dutheil, F. COVID-19: An Economic or Social Disease? Implications for Disadvantaged Populations. J. Risk Financ. Manag. 2021, 14, 587. [CrossRef]

84. Szustak, G.; Witold, G.; Szewczyk, L. Household Financial Situation during the COVID-19 Pandemic with Particular Emphasis on Savings-An Evidence from Poland Compared to Other CEE States. Risks 2021, 9, 166. [CrossRef]

85. Kurowski, Ł. Household's Overindebtedness during the COVID-19 Crisis: The Role of Debt and Financial Literacy. Risks 2021, 9 , 62. [CrossRef]

86. UN. Women and the Sustainable Development Goals (SDGs). Available online: https://www.unwomen.org/en/news/in-focus/ women-and-the-sdgs (accessed on 20 December 2021).

87. Sun, S.; Li, T.; Ma, H.; Li, R.Y.M.; Gouliamos, K.; Zheng, J.; Han, Y.; Manta, O.; Comite, U.; Barros, T.; et al. Does Employee Quality Affect Corporate Social Responsibility? Evidence from China. Sustainability 2020, 12, 2692. [CrossRef]

88. Lozano, R.; Barreiro-Gen, M. Disrupting the brave new world: COVID-19 effects on organisations' sustainability efforts. J. Organ. Change Manag. 2021, 34, 613-628. [CrossRef] 